\title{
DETERMINAN PENYALAHGUNAAN NARKOBA PADA REMAJA DI SMAN 24 JAKARTA
}

\author{
Oki Fitriani $^{1}$, Sarah Handayani ${ }^{2}$, Nur Asiah ${ }^{2}$ \\ 1) Rumah Sakit Ibu Anak Asih, Jakarta \\ 2) Program Studi Kesehatan Masyarakat, Fakultas Ilmu-Ilmu Kesehatan, \\ Universitas Muhammadiyah Prof. Dr. HAMKA \\ Email: okifitriani@gmail.com
}

\begin{abstract}
Determinants of Drug Abuse Among Adolescents in 24 Senior High School Jakarta
\end{abstract}

\begin{abstract}
Introduction. The number of drug abuse in adolescents has increased dramatically. Survey conducted in 2006 and 2009 shows pattern that drug abuse risk in big city is higher rather than in small city. It is also identified that the risk level of drug abuse in adolescents is different from one to another. The differences are caused by several factors. This study aims to determine some factors believed to have association with the risk of drug abuse in adolescents in 24 Senior High School, Jakarta.

Methods. This study is a quantitative analytical research using cross sectional design. Location of the study was in 24 Senior High School, Jakarta. Research was conducted during March - August 2016. Population of this study was all student grade 10 and 11 in 24 Senior High School, Jakarta which is 350 students. Variable dependent in this study is drug abuse risk and independent variables are individual, drug and environment characteristic. Sampling was chosen using proportional stratified random sampling. The total sample was 91 people. Data analysis was using uni variate and bivariate analysis.

Resulst. The results showed from 8 variables, only 6 variables that have relationship with the risk of drug abuse in teenagers / students. Those variables are drug factors; availability ( $p$ value $=0.000 P R=2,5$ 95\% CI 1566-3909), and the ease of getting drugs ( $p$ value $=0,009 P R=1,795 \%$ CI 1114-2437), individual factors; gender ( $p$ value $=0,000 P R=2,695 \% C I$ 0626-4218), and knowledge ( $p$ value = $0048 P R=1,595 \%$ CI 0966-2340), environmental factors; family ( $p$ value $=0.003 P R=1,895 \% C I$ 1174-2739), and friends (association) ( $p$ value $=0,000 P R=2,495 \%$ CI 1512-3647).
\end{abstract}

Conclusions. Variables that have relationship with the risk of drug abuse are drug factors (availability, the ease of getting drugs) individual factors (gender, knowladge) and environment factors (family, friend)

Keywords: Adolescents, Risk of Drug Abuse

\section{PENDAHULUAN}

Kenakalan remaja sebagai salah satu masalah sosial sangat mengganggu keharmonisan dan keutuhan segala nilai serta kebutuhan dasar dalam kehidupan sosial. Pada hakikatnya kenakalan remaja bukanlah suatu masalah sosial yang hadir dengan sendirinya di tengah-tengah masyarakat, masalah tersebut muncul karena beberapa keadaan yang berkaitan atau bahkan keadaan yang mendukung kenakalan itu sendiri.

Kenakalan yang dilakukan oleh remaja memiliki jenis yang beragam, mulai dari kenakalan biasa seperti berbohong, membolos, pulang larut malam, hingga kenakalan khusus seperti melakukan praktik seks pranikah, aborsi, penyalahgunaan Narkotika dan Obat atau Bahan Berbahaya (Narkoba) dan lain-lain (Sudarsono, 2005).
Penyalahgunaan narkoba sendiri belakangan ini menjadi topik yang hangat diperbincangkan. Tingginya angka peredaran narkoba yang dilakukan oleh oknum di masyarakat menjadi hal yang penting untuk diperhatikan, karena saat ini narkoba telah merambah tidak hanya pada kelompok pekerja ataupun orang dewasa namun peredaran narkoba juga telah merambah ke pelajar baik di tingkat sekolah dasar, menengah maupun atas.

Berdasarkan laporan tahunan dari United Nations Office on Drugs and Crime (UNODC), 2013 menyebutkan bahwa pada tahun 2011, diperkirakan antara 167 sampai dengan 315 juta orang $(3,6-6,9 \%$ dari populasi penduduk dunia yang berumur 15-64 tahun) menggunakan 
narkoba minimal sekali dalam setahun (BNN, 2014).

Menurut laporan UNODC pada tahun 2015, diperkirakan sebanyak 187.100 orang di dunia telah meninggal akibat narkoba pada tahun 2013. Asia sendiri menjadi wilayah yang paling tinggi menyumbangkan angka kematian akibat narkoba pada tahun 2013, yakni sebesar 81.100 orang.

Angka Penyalahguna narkoba di Indonesia diperkirakan berjumlah sekitar 3,8 juta sampai 4,1 juta orang pada kelompok usia 10-59 tahun di tahun 2014 diperkirakan jumlah penyalahguna narkoba meningkat menjadi 5 juta orang pada tahun 2020. Hal tersebut menjadikan Indonesia sebagai negara yang memiliki peringkat teratas dalam peredaran narkotika (BNN, 2015).

Berdasarkan hasil survey Badan Narkotika Nasional (BNN) tahun 2009 diperoleh data bahwa rata-rata usia pertama kali menyalahgunakan narkoba pada usia yang sangat muda, yaitu 12-15 tahun. Sedangkan berdasarkan laporan tahunan yang dirilis oleh BNN tahun 2014, diperoleh data bahwa rata-rata usia pertama kali menyalahgunakan narkoba yakni pada usia 10 tahun dengan jenis narkoba suntik.

Angka penyalahgunaan narkoba di kalangan pelajar Indonesia untuk kategori pernah pakai yakni sebesar 7,5\%, angka tersebut berbeda menurut jenis kelamin, usia dan jenjang pendidikan. Hasil survei tahun 2006 dan 2009 menunjukkan pola bahwa kejadian penyalahgunaan narkoba relatif lebih tinggi di kota besar dibandingkan di kota kecil. Hal ini mengindikasikan bahwa peredaran narkoba lebih marak di kota-kota besar dalam setahun terakhir (BNNP DKI Jakarta, 2013).

Berdasarkan Laporan Akhir Survei Nasional Perkembangan Penyalahguna Narkoba Tahun Anggaran 2014 yang dirilis pada tahun 2015, diungkapkan bahwa provinsi DKI Jakarta memiliki prevalensi angka penyalahgunaan narkoba yang paling tinggi dibandingkan provinsi-provinsi lainnya, yakni sebesar $4,73 \%$. Hal tersebut semakin menggambarkan bahwa pelajar yang berada di wilayah DKI Jakarta mempunyai risiko yang tinggi menjadi target sasaran bagi peredaran dan penyalahgunaan narkoba. Menurut laporan tersebut juga diperkirakan bahwa tahun 2015 penyalahgunaan narkoba pada kelompok pelajar atau mahasiswa di provinsi DKI Jakarta berjumlah 92.800 orang dan diperkirakan akan terus melonjak.

Wilayah DKI Jakarta yang dinilai rawan menjadi lokasi penyalahgunaan narkoba adalah wilayah Jakarta Barat dan Jakarta Pusat. Hal tersebut dikarenakan di kedua wilayah tersebut banyak terdapat tempat hiburan yang rawan menjadi lokasi peredaran narkoba. Selain tempat hiburan, di kedua wilayah tersebut juga banyak terdapat hotel yang menjadi tempat transit orangorang dari berbagai tempat sehingga memudahkan pihak-pihak yang terkait jaringan narkoba untuk melancarkan aksinya (Kurniawan, 2013). Sedangkan di wilayah Jakarta Pusat sendiri penyebaran narkoba banyak terdapat di wilayah Tanah Tinggi, Kampung Bali, Tanah Abang, Kampung Bonang, dan Duri Pulo (Kabar Terkini, 2016).

Diketahui bahwa faktor risiko penggunaan narkoba sangat bervariasi dan berbeda-beda antara satu dengan yang lainnya, penyalahgunaan narkoba dapat terjadi akibat interaksi dari berbagai faktor, seperti faktor narkoba, faktor individu, serta faktor lingkungan. Selain itu, diyakini bahwa beberapa orang memiliki risiko yang lebih besar dibandingkan orang yang lain dalam penyalahgunaan narkoba.

Pendeteksian risiko pada remaja sangat penting dilakukan, karena dengan mendeteksi risiko penyalahgunaan narkoba pada remaja dengan sedini mungkin diharapkan dapat mengurangi tingkat penyalahgunaan narkoba 
yang terjadi pada remaja, sehingga generasi muda dapat terselamatkan dari bahaya narkoba yang ditimbulkan. Oleh karena itu, dalam penelitian ini penulis ingin mengetahui hubungan faktor narkoba, faktor individu dan faktor lingkungan terhadap risiko penyalahgunaan narkoba pada remaja di SMAN 24 Jakarta. SMA ini dipilih karena berada di wilayah provinsi DKI Jakarta, yang mana memiliki prevalensi angka penyalahgunaan narkoba paling tinggi dibandingkan provinsi-provinsi lainnya. Ditambah lagi sekolah tersebut masuk kedalam wilayah Jakarta Pusat yang memiliki tingkat kerawanan tinggi dibanding wilayah DKI Jakarta lainnya.

\section{METODE}

Penelitian ini adalah penelitian analitik kuantitatif, dengan desain penelitian cross sectional. Lokasi Penelitian ini adalah di SMAN 24 Jakarta yang berlokasi di Jl. Lapangan Tembak No.1, Gelora, Tanah Abang, Jakarta Pusat. Waktu penelitian ini dilakukan pada bulan Maret-Agustus tahun 2016. Sedangkan waktu pengumpulan data dilaksanakan pada tanggal 30 Mei sampai 2 Juni tahun 2016.

Variabel dependen penelitian ini adalah risiko penyalahgunaan narkoba dan variabel independennya terdiri dari variabel karakteristik individu, narkoba dan lingkungan. Populasi penelitian ini adalah seluruh siswa/I kelas $\mathrm{X}$ dan XI SMAN 24 Jakarta, yang berjumlah 350 orang. Teknik pengambilan sampel dilakukan dengan metode Proportional Stratification Random Sampling, yang kemudian dari rumus stratifikasi dan penambahan sampel $20 \%$, didapatkan total sampel berjumlah 91 responden.
Pada penelitian ini data dikumpulkan melalui data primer dan data sekunder. Data primer diperoleh dari kuesioner yang dikumpulkan oleh peneliti. Sedangkan data sekunder diperoleh dari dokumen atau arsip dari SMAN 24 Jakarta. Analisis data pada penelitian ini dilakukan secara bertahap dari analisis univariat kemudian analisis bivariat.

\section{HASIL}

Hasil penelitian menunjukkan bahwa sebanyak $56 \%$ responden berisiko besar untuk menyalahgunakan narkoba. Dalam karakteristik responden, diketahui bahwa sebanyak 52,7\% responden berjenis kelamin laki-laki. Hasil penelitian menunjukkan sebanyak $63.7 \%$ responden memiliki pengetahuan yang kurang baik tentang narkoba. Sebanyak 63,8\% responden memiliki sikap yang positif (pro) terhadap penyalahgunaan narkoba.

Pada variabel karakteristik ketersediaan narkoba diketahui sebanyak $51,6 \%$ responden menganggap bahwa narkoba tersedia di lingkungan sosial responden. Diketahui bahwa sebanyak sebanayak $50,5 \%$ responden menganggap narkoba mudah didapat di lingkungan sosial responden. Pada variabel lingkungan, berdasarkan hasil analisis univariat diketahui bahwa sebanyak sebanyak 54,9\% responden memiliki kondisi lingkungan keluarga yang kurang baik. Sebanyak 50,5\% responden memiliki lingkungan teman (pergaulan) yang mempengaruhi responden dalam hal penyalahgunaan narkoba. Diketahui bahwa sebanyak $52,7 \%$ responden berpendapat bahwa keadaan lingkungan sekolah responden turut mendorong terjadinya penyalahgunaan narkoba (tabel 1). 
Tabel 1 Deskripsi Risiko Penyalahgunaan Narkoba dan Determinannya

\begin{tabular}{lll}
\hline \multicolumn{1}{c}{ Variabel Dependen } & n & \% \\
\hline Risiko Penyalahgunaan Narkoba & & \\
1. Berisiko Besar Menyalahgunakan & 51 & 56 \\
2. Berisiko Kecil Menyalahgunakan & 40 & 44 \\
Jenis Kelamin & & \\
1. Laki-laki & 48 & 52.7 \\
2. Perempuan & 43 & 47.3 \\
Pengetahuan & & \\
1. Kurang baik & 58 & 63.7 \\
2. Baik & 33 & 36.3 \\
Sikap & & \\
1. Positif (pro) terhadap penyalahgunaan narkoba & 49 & 53.8 \\
2. Negatif (kontra) terhadap penyalahgunaan narkoba & 42 & 46.2 \\
Ketersediaan Narkoba & & \\
1. Tersedia & 47 & 51.6 \\
2. Tidak Tersedia & 44 & 48.4 \\
Kemudahan Mendapatkan Narkoba & & \\
1. Mudah Didapat & 46 & 50.5 \\
2. Sulit Didapat & 45 & 49.5 \\
Lingkungan keluarga & & \\
1. Kurang baik & 50 & 54.9 \\
2. Baik & 41 & 45.1 \\
Lingkungan teman (pergaulan) & & \\
1. Mempengaruhi & 46 & 50.5 \\
2. Tidak mempengaruhi & 45 & 49.5 \\
Lingkungan sekolah & & \\
1. Mendorong terjadinya penyalahgunaan narkoba & 48 & 52.7 \\
2. Tidak mendorong terjadinya penyalahgunaan narkoba & 43 & 47.3 \\
\hline
\end{tabular}

Tabel 2 Hasil Analisis Bivariat

\begin{tabular}{lcc}
\hline \multicolumn{1}{c}{ Variabel Independen } & $\boldsymbol{p}$ value & PR (95\% CI) \\
\hline Ketersediaan narkoba & 0.000 & $2.474(1.566-3.909)$ \\
Kemudahan mendapatkan narkoba & 0.009 & $1.648(1.114-2.437)$ \\
Jenis kelamin & 0.000 & $2.619(0.626-4.218)$ \\
Pengetahuan & 0.048 & $1.504(0.966-2.340)$ \\
Sikap terhadap penyalahgunaan narkoba & 0.282 & $1.224(0.841-1.783)$ \\
Lingkungan keluarga & 0.003 & $1.794(1.174-2.739)$ \\
Lingkungan teman (pergaulan) & 0.000 & $2.348(1.512-3.647)$ \\
Lingkungan sekolah & 0.375 & $1.181(0.815-1.711)$ \\
\hline
\end{tabular}

Berdasarkan tabel 2, diketahui bahwa terdapat dua variabel yang tidak memiliki hubungan dengan risiko penyalahgunaan narkoba pada remaja di SMAN 24 Jakarta tahun 2016, yaitu variabel sikap terhadap penyalahgunaan narkoba $(p$ value $=0,282 \mathrm{PR}=$ $1,22495 \%$ CI $0.841-1.783)$ dan lingkungan sekolah $(p$ value $=0,375 \mathrm{PR}=1,18195 \% \mathrm{CI}$ $0,815-1,711)$.

\section{PEMBAHASAN}

Risiko penyalahgunaan pada remaja harus dideteksi sejak dini, mengetahui ciri-ciri ataupun karakteristik seorang remaja yang berisiko merupakan hal penting dalam upaya pencegahan terhadap penyalahgunaan narkoba pada remaja.

Pada penelitian ini, diketahui bahwa sebanyak 56\% remaja di SMAN 24 Jakarta pada tahun 2016 yang menjadi objek penelitian, berisiko besar meyalahgunakan narkoba. Tidak jauh berbeda dengan hasil penelitian yang dilakukan oleh Jaji pada tahun 2009, bahwa sebanyak 52,30\% remaja SMP dan SMA kota palembang pun telah berada pada kategori berisiko tinggi menyalahgunakan narkoba oleh karena itu dari hasil penelitian yang didapatkan oleh peneliti ini pun sekiranya dapat digeneralisir bahwa lebih dari setengah (> 50\%) pelajar yang bersekolah di DKI Jakarta saat ini 
berada dalam kategori berisiko besar menyalahgunakan narkoba.

Saat ini para remaja sudah tidak menganggap asing perilaku merokok dan minum-minuman beralkohol, padahal sebagaimana diketahui bahwa perilaku merokok dan minum-minuman beralkohol merupakan pintu awal seseorang untuk terjerumus kedalam penyalahgunaan narkoba.

Hal tersebut dibuktikan dengan hasil temuan peneliti, dimana $31,9 \%$ responden mengaku pernah merokok dan diketahui sebanyak 28,6\% responden mengaku pernah minum-minuman beralkohol. Beberapa dari responden bahkan memulainya pada usia yang sangat muda yakni usia 10 tahun untuk perilaku merokok dan usia 11 tahun pada perilaku minum-minuman beralkohol.

Seperti yang telah diungkapkan oleh Piget dalam Ali (2005) bahwa pada masa remaja muncul beberapa sifat yang unik, salah satunya adalah sifat ingin meniru sesuatu yang dilihat dan meniru lingkungannya. Untuk itu sebaiknya kondisi lingkungan, baik dari lingkungan keluarga, teman ataupun sekolah memiliki kondisi yang baik agar hasil dari proses tumbuh kembang remaja pun baik.

Pada penelitian ini diketahui bahwa sebanyak 52,7\% remaja di SMAN 24 Jakarta pada tahun 2016 yang menjadi objek penelitian adalah berjenis kelamin laki-laki. Remaja dengan jenis kelamin laki-laki memiliki risiko yang lebih besar untuk menyalahgunakan narkoba $(79,2 \%)$, dibandingkan remaja yang remaja dengan jenis kelamin perempuan $(30,2 \%)$.

Hasil uji Chi-Square pada penelitian ini menunjukkan adanya hubungan antara jenis kelamin terhadap risiko penyalahgunaan narkoba pada remaja di SMAN 24 Jakarta tahun 2016 ( $p$ value 0,000 ).

Penelitian ini hampir sejalan dengan Laporan Akhir Survei Nasional Perkembangan Penyalahguna Narkoba Tahun Anggaran 2014 yang dirilis oleh BNN yang menyatakan bahwa jenis kelamin laki-laki memang memiliki prevalensi penyalahgunaan narkoba yang lebih besar dibandingkan perempuan, yakni sebesar $7,78 \%$, sedangkan pada perempuan sebesar $2,14 \%$.

Hal tersebut dapat dipahami karena berdasarkan teori yang ada, laki-laki memang cenderung lebih mudah bereaksi dan lebih agresif terhadap gangguan atau rangsangan luar yang mempengaruhinya. Selain itu lebih cenderung melakukan tindakan-tindakan yang bersifat irasional, melakukan sesuatu tanpa berpikir terlebih dahulu, cenderung, mudah tersinggung sehingga mudah terjadi perkelahian atau tawuran, suka mencari perhatian, dan bertindak tanpa berpikir terlebih dahulu.

Pengetahuan merupakan domain yang sangat penting dalam membentuk tindakan seseorang. Perilaku yang dilakukan berdasarkan pada pengetahuan akan bertahan lebih lama dan kemungkinan menjadi perilaku yang melekat pada seseorang dibandingkan jika tidak berdasarkan pengetahuan (Notoatmodjo, 2003). Pada penelitian ini, diketahui bahwa sebanyak 63,7\% remaja di SMAN 24 Jakarta pada tahun 2016 yang menjadi objek penelitian, memiliki pengetahuan tentang narkoba yang kurang baik.

Hasil uji Chi-Square pada penelitian ini menunjukkan adanya hubungan antara pengetahuan remaja mengenai narkoba terhadap risiko penyalahgunaan narkoba pada remaja di SMAN 24 Jakarta ( $p$ value 0,048 ). Keterbatasan pemahaman dan pengetahuan remaja mengenai narkoba tentu dapat membawa remaja ke arah perilaku berisiko termasuk dalam menyalahgunakan narkoba.

Penelitian ini juga hampir sejalan dengan hasil penelitian yang dilakukan oleh Hidayati (2012), bahwa pengetahuan yang tinggi (59\%) pada remaja, membuat remaja memiliki upaya pencegahan yang lebih baik terhadap penyalahgunaan narkoba $(64,6 \%)$, dibandingkan dengan pengetahuan yang rendah. Pengetahuan yang baik sejatinya membantu mencegah seorang remaja untuk terhindar dari penyalahgunaan narkoba. Sebaliknya, pengetahuan yang kurang baik dapat mendorong atau meningkatkan risiko remaja terhadap penyalahgunaan narkoba. 
Dengan mengetahui sikap seseorang, kita dapat menduga bagaimana respon atau perilaku yang akan diambil oleh orang yang bersangkutan terhadap suatu masalah atau keadaan yang dihadapkan kepadanya.

Pada penelitian ini diketahui bahwa, sebanyak 53,8\% remaja di SMAN 24 Jakarta pada tahun 2016 yang menjadi objek penelitian memiliki sikap yang positif (pro) terhadap penyalahgunaan narkoba.

Dengan tingginya angka remaja yang positif (pro) terhadap penyalahgunaan narkoba (53.8\%), maka hal tersebut harus menjadi perhatian khusus, oleh karena itu kesadaran akan bahaya narkoba, dampak yang ditimbulkan serta pengetahuan akan narkoba sendiri tentunya harus ditingkatkan kepada remaja.

Hasil uji Chi-Square pada penelitian ini menunjukkan tidak adanya hubungan antara sikap terhadap penyalahgunaan narkoba terhadap risiko penyalahgunaan narkoba pada remaja di SMAN 24 Jakarta ( $p$ value $=0,282$ ).

Penelitian ini sejalan dengan penelitian yang dilakukan oleh Rustyawati (2005) bahwa sikap terhadap penyalahgunaan narkoba tidak memiliki hubungan dengan kasus penyalahgunaan narkoba.

Meskipun dalam hasil uji bivariat tidak ada hubungan antara sikap remaja terhadap penyalahgunaan narkoba dengan risiko penyalahgunaan narkoba, namun bukan berarti sikap remaja tidak perlu mendapat perhatian khusus. Telah diketahui bahwa sikap merupakan suatu ekspresi perasaan seseorang yang merekfleksikan kesukaan atau ketidaksukaan terhadap suatu objek. Sikap juga merupakan faktor terpenting atau sebagai prediktor dari niat untuk aktivitas fisik dan perilaku. Selain itu, sikap juga dapat mempengaruhi seseorang dalam pengambilan keputusan, sehingga sikap remaja yang pro terhadap penyalahgunaan narkoba tetap dapat membahayakan bagi seorang remaja.

Ketersediaan serta peredaran zat-zat narkoba di lingkungan remaja memberikan pengaruh besar terhadap penyalahgunaan narkoba. Semakin banyak zat (narkoba) beredar di lingkungan remaja maka semakin tinggi pula risiko remaja untuk jatuh kedalam penyalahgunaan narkoba.

Pada penelitian ini, diketahui bahwa sebanyak 51,6\% remaja di SMAN 24 Jakarta pada tahun 2016 yang menjadi objek penelitian memiliki persepsi atau anggapan bahwa zat-zat narkoba tersedia di lingkungan temannya (pergaulan) yakni 61,5\%. Selain itu, zat yang dianggap tersedia di lingkungan sosial remaja adalah zat narkoba jenis inhalan $(74,7 \%)$ dan minum-minuman beralkohol $(71,4 \%)$.

Hasil uji Chi-Square penelitian ini menunjukkan adanya hubungan antara ketersediaan zat-zat narkoba di lingkungan sosial remaja terhadap risiko penyalahgunaan narkoba pada remaja di SMAN 24 Jakarta tahun 2016 ( $p$ value $=0,000)$.

Seperti diketahui bahwa persepsi seseorang terhadap suatu hal dapat dipengaruhi oleh beberapa faktor, diantaranya faktor eksternal yaitu faktor yang diperoleh dari stimulus yang diterima oleh indra, baik indra penglihatan, pendengaran maupun indra perasa. Banyaknya remaja yang memiliki persepsi tentang ketersediaan atau adanya zat narkoba di lingkungan remaja $(51,6 \%)$ dapat diasumsikan bahwa remaja pernah bersinggungan dengan satu atau lebih dengan zat-zat narkoba, baik melihatnya secara langsung maupun mendengar mengenai ketersediaannya dari lingkungan mereka. Hal tersebut yang dapat membuat remaja semakin berisiko untuk menyalahgunakan narkoba.

Peningkatan akses terhadap narkoba selama masa remaja dapat menjadi faktor yang berkontribusi terhadap inisiasi penyalahgunaan narkoba. Mudahnya akses remaja, murahnya zat-zat narkoba yang dijual, serta semakin beragamnya jenis-jenis narkoba yang berada di lingkungan, sangat berbahaya bagi remaja.

Pada penelitian ini, diketahui bahwa sebanyak 50,5\% remaja di SMAN 24 Jakarta pada tahun 2016 yang menjadi objek penelitian memiliki persepsi atau anggapan bahwa zat-zat narkoba mudah didapat di lingkungan sosial remaja dan lingkungan yang dianggap paling mudah untuk mendapatkan narkoba adalah 
lingkungan pergaulan $62,6 \%$. Selain itu, zat yang dianggap tersedia di lingkungan sosial remaja adalah zat narkoba jenis inhalan dengan persentase jawaban sangat mudah sebesar $59,3 \%$, dan minum-minuman beralkohol dengan persentase jawaban sangat mudah sebesar $42,9 \%$.

Hasil uji Chi-Square pada penelitian ini menunjukkan adanya hubungan antara kemudahan mendapatkan zat-zat narkoba di lingkungan sosial remaja terhadap risiko penyalahgunaan narkoba pada remaja di SMA N 24 Jakarta ( $p$ value $=0.009$ ).

Persepsi mengenai kemudahan mendapatkan narkoba juga dapat diperoleh responden dari stimulus yang diterima oleh indra, baik indra penglihatan, pendengaran maupun indra perasa. Banyaknya remaja yang memiliki persepsi tentang kemudahan mendapatkan zat narkoba di lingkungan remaja $(50,5 \%)$ dapat diasumsikan bahwa remaja pernah bersinggungan dengan satu atau lebih dengan zat-zat narkoba, baik melihatnya secara langsung maupun mendengar mengenai kemudahan mendapatkannya dari lingkungan mereka.

Lingkungan keluarga merupakan hal yang sangat penting dalam membentuk perilaku seseorang. Telah diketahui bahwa kondisi keluarga, baik secara langsung maupun tidak langsung memiliki pengaruh kepada seseorang dalam hal peyalahgunaan narkoba.

Pada penelitian ini, diketahui bahwa sebanyak 54,9\% remaja di SMAN 24 Jakarta pada tahun 2016 yang menjadi objek penelitian, memiliki kondisi lingkungan keluarga yang kurang baik. Hasil uji Chi-Square menunjukkan adanya hubungan antara lingkungan keluarga terhadap risiko penyalahgunaan narkoba pada remaja di SMAN 24 Jakarta ( $p$ value $=0,003$ ).

Hasil penelitian ini hampir sejalan dengan penelitian yang dilakukan oleh Rustyawati (2005) bahwa keharmonisan keluarga memiliki hubungan dengan penyalahgunaan narkoba OR =5.4). Kemudian diperkuat oleh penelitian yang dilakukan oleh Hawari (2006) yang mengkatakan bahwa seseorang yang berada di dalam lingkungan keluarga yang tidak baik memiliki risiko relatif 7,9 untuk terlibat penyalahgunaan narkoba.

Menurut Soetjiningsih (2004), keluarga memiliki pengaruh yang cukup besar bagi perkembangan remaja karena keluarga merupakan lingkungan sosial pertama yang meletakkan dasar-dasar kepribadian remaja. Dalam hal penyalahgunaan narkoba, seperti yang dikemukakan oleh Hawari (2006), seseorang yang berada dalam kondisi keluarga yang tidak baik (disfungsi keluarga) akan merasa tertekan. Ketertekanannya tersebut dapat mendorong seseorang untuk terlibat penyalahgunaan atau ketergantungan narkoba.

Lingkungan teman atau pergaulan merupakan lingkungan kedua setelah keluarga yang memiliki pengaruh pula terhadap pertumbuhan dan perkembangan seseorang. Dalam hal penyalahgunaan narkoba, lingkungan ini diketahui sebagai salah satu lingkungan dimana perilaku yang mengarah kepada penyalahgunaan narkoba mulai muncul.

Pada penelitian ini, diketahui bahwa sebanyak $50,5 \%$ remaja yang menjadi objek penelitian memiliki kondisi lingkungan teman (pergaulan) yang dapat mempengaruhi remaja dalam hal menyalahgunakan narkoba. Hasil uji Chi-Square pada penelitian ini menunjukkan adanya hubungan antara lingkungan teman (pergaulan) terhadap risiko penyalahgunaan narkoba pada remaja di SMAN 24 Jakarta ( $p$ value $=0,000$ ).

Hal yang serupa dengan hasil penelitian yang dilakukan oleh Rahmadona (2014) mengungkapkan bahwa terdapat hubungan yang bermakna antara peran teman sebaya terhadap penyalahgunaan narkoba. Memiliki teman sebaya yang memperkenalkan dan menyalahgunakan narkoba membuat seseorang berisiko 19 kali lebih besar menyalahgunakan narkoba dibandingkan seseorang tidak memiliki teman sebaya yang memperkenalkan dan menyalahgunakan narkoba

Telah diketahui bahwa, remaja lebih banyak menghabiskan waktunya bersama teman-teman, sehingga lingkungan pergaulan juga memiliki andil dalam meningkatkan risiko penyalahgunaan narkoba pada remaja. Kegiatan 
dari pergaulan dapat menciptakan keterikatan dan kebersamaan hingga akhirnya membuat remaja sulit melepaskan diri hal tersebut akan menjadi hal yang berbahaya apabila seorang remaja bergaul dengan teman yang melakukan perilaku dan kebiasaan negatif seperti merokok, minum-minuman beralkohol hingga penyalahgunaan narkoba. Berdasarkan hasil dari study klasik Asch (1958) mengenai pengaruh (konformitas) dikemukakan bahwa enam dari sembilan orang dalam suatu kelompok cenderung akan memiliki perilaku atau kebiasaan yang sama.

Sekolah merupakan lingkungan pendidikan sekunder bagi anak yang sudah bersekolah maka lingkungan yang setiap hari dimasukinya selain lingkungan rumah adalah lingkungan sekolah.

Pada penelitian ini diketahui bahwa sebanyak 52,7\% remaja di SMAN 24 Jakarta pada tahun 2016 yang menjadi objek penelitian memiliki anggapan bahwa kondisi lingkungan sekolah mereka ikut mendorong terjadinya penyalahgunaan narkoba. Hasil uji Chi-Square pada penelitian ini menunjukkan tidak adanya hubungan antara lingkungan sekolah terhadap risiko penyalahgunaan narkoba pada remaja di SMAN 24 Jakarta ( $p$ value $=0,375$ ).

Dalam hal risiko penyalahgunaan narkoba meskipun dalam hasil penelitian ini sekolah tidak memiliki hubungan dengan risiko penyalahgunaan narkoba pada remaja, namun bukan berarti sekolah dapat lepas tangan terhadap kasus penyalahgunaan narkoba. Sekolah harus memiliki peran penting dalam pencegahan penyalahgunaan narkoba khususnya pada pelajar, karena berdasarkan penelitian yang dilakukan oleh BNN pada tahun 2014, dikatakan bahwa penyalahgunaan narkoba yang dilakukan oleh pelajar akan mengalami peningkatan yang cukup signifikan pada tahuntahun mendatangn.

Peneliti menyarankan diperlukan kerja sama yang komprehensif baik dari remaja yang bersangkutan, orang tua, sekolah, maupun BNN atau Kepolisian, guna menurunkan risiko dan angka penyalahgunaan narkoba pada remaja.

Remaja perlu mempunyai gaya hidup yang lebih cermat, orang tua perlu mengawasi dan mengontrol kegiatan anak, pihak sekolah dapat meningkatkan pengetahuan siswa dan siswinya melalui kegiatan-kegiatan yang bersifat edukasi, dan pihak BNN ataupun Kepolisian dapat terus melakukan kegiatan pemberatasan peredaran gelap narkoba, serta melakukan kegiatan-kegiatan pencegahan baik di sekolah maupun di masyarakat.

\section{KESIMPULAN}

Sebanyak 56\% remaja di SMAN 24 Jakarta pada tahun 2016 yang menjadi objek penelitian berisiko besar meyalahgunakan narkoba. Selain itu, hasil penelitian menunjukkan dari delapan variabel, hanya enam variabel yang memiliki hubungan dengan risiko penyalahgunaan narkoba pada remaja atau pelajar. Variabel tersebut antara lain faktor narkoba, ketersediaan dan kemudahan mendapatkan narkoba faktor individu, jenis kelamin dan pengetahuan dan faktor lingkungan, keluarga dan teman (pergaulan). Sedangkan variabel sikap dan lingkungan sekolah tidak menunjukkan adanya hubungan signifikan terhadap perilaku risiko penyalahgunaan narkoba.

\section{ABSTRAK}

Pendahuluan. Angka penyalahgunaan narkoba pada remaja mengalami peningkatan yang drastis. Hasil survei tahun 2006 dan 2009 menunjukkan pola bahwa kejadian penyalahgunaan narkoba relatif lebih tinggi di kota besar dibanding di kota kecil. Diketahui bahwa tingkat risiko penyalahgunaan narkoba pada remaja berbeda antara satu dengan yang lain, perbedaan risiko tersebut disebabkan oleh beberapa faktor. Penelitian ini bertujuan untuk mengetahui beberapa faktor yang diyakini memiliki hubungan dengan risiko penyalahgunaan narkoba pada remaja di SMAN 24 Jakarta.

Metode. Penelitian ini adalah penelitian analitik kuantitatif dengan desain studi cross sectional. Lokasi penelitian adalah SMAN 24 Jakarta. Waktu penelitian ini dilakukan pada bulan Maret Agustus 2016. Populasi penelitian ini adalah seluruh siswa dan siswi kelas X dan XI SMAN 24 Jakarta, yang berjumlah 350 orang. Variabel dependen penelitian ialah risiko penyalahgunaan narkoba 
dan variabel independennya adalah variabel karakteristik individu, narkoba dan lingkungan. Pengambilan sampel dilakukan dengan menggunakan metode proportional stratification random sampling, dengan total sampel berjumlah 91 orang. Analisis data penelitian dilakukan dengan melakukan analisis univariat dan bivariat.

Hasil. Hasil penelitian menunjukkan dari delapan variabel, hanya enam variabel yang memiliki hubungan dengan risiko penyalahgunaan narkoba pada remaja/pelajar, variabel tersebut antara lain faktor narkoba; ketersediaan ( $p$ value $=0.000 \mathrm{PR}=2.595 \%$ CI $1.566-3.909$ ), dan kemudahan mendapatkan narkoba ( $p$ value $=0.009 \mathrm{PR}=1.795 \% \mathrm{CI} 1.114-2.437)$, faktor individu, jenis kelamin ( $p$ value $=0.000 \mathrm{PR}=2.695 \% \mathrm{CI} 0.626-4.218)$, dan pengetahuan $(p$ value $=0.048 \mathrm{PR}=1.595 \% \mathrm{CI}$ $0.966-2.340)$, faktor lingkungan, keluarga $(p$ value $=0.003 \mathrm{PR}=1.895 \%$ CI $1.174-2.739)$ dan teman (pergaulan) ( $p$ value $=0.000 \mathrm{PR}=2.495 \%$ CI $1.512-3.647$ ).

Kesimpulan. Variabel yag berhubungan dengan risiko penyalahgunaan narkoba adalah faktor narkoba (ketersediaan, kemudahan mendapatkan narkoba), faktor individu (jenis kelamin, penengetahuan) dan faktor lingkungan (keluarga, teman).

Kata kunci: Remaja, Risiko Penyalahgunaan Narkoba, Faktor Narkoba, Faktor Individu, Faktor Lingkungan

\section{DAFTAR PUSTAKA}

1. Ali, M., M. Asrori. (2005). Psikologi Remaja Perkembangan Peserta Didik Edisi Kedua. Jakarta: Bumi Aksara.

2. BNN. (2009). Pedoman Petugas Penyuluh di Lingkungan Umum. Jakarta: BNN RI

3. BNN. (2014). Jurnal data P4GN 2013 edisi 2014. Jakarta: BNN RI.

4. BNN. (2015). Laporan Akhir Survey Nasional Perkembangan Penyalahguna Narkoba Tahun Anggaran 2014. Jakarta: BNN.

5. BNNP DKI Jakarta. (2013). Pelajar dan Bahaya Narkotika. Jakarta: BNNP DKI Jakarta

6. Hawari, Dadang. (2006). Penyalahgunaan \& Ketergantungan NAZA (Narkotika, Alkohol \& Zat Adiktif) Edisi Kedua. Jakarta: Balai Penerbit FKUI.

7. Hidayati, Putri Eka dan Indrawati. (2012). Gambaran Pengetahuan Dan Upaya Pencegahan Terhadap Penyalahgunaan Narkoba Pada Remaja di SMK Negeri 2 Sragen Kabupaten Sragen. GASTER, Vol. 9, No.1 Februari 2012.

8. Jaji. (2009). Hubungan Faktor Sosial dan Spiritual dengan Risiko Penyalahgunaan Napza pada Remaja SMP dan SMA di Kota Palembang 2009.

9. Kabar Terkini. (2016). Ini 20 Lokasi Peredaran Narkoba Di Jakarta. (21 Januari 2016). Diakses dari http://kabarterkini.top/berita/ini-20-lokasi-peredaran- narkoba-di-jakarta/5278044. pada tanggal 27 Januari 2016.

10. Kurniawan, Bahri. (2013). Jakarta Pusat dan Jakarta Barat Rawan Narkoba. (8 Februari 2013). Diakses dari

http://www.tribunnews.com/metropolitan/2013/02/08

/jakarta-pusat-dan-jakarta-barat-daerah-rawannarkoba. Pada tanggal 27 November 2015.

11. Notoatmodjo, Soekidjo.p (2003). Ilmu Kesehatan Msyarakat. Jakarta: PT Rineka Cipta.

12. Rahmadona, Elviza, Helfi Agustin. (2014). Faktorfaktor yang Berhubungan dengan Penyalahgunaan Narkoba di RSJ Prof. HB. Sa'anin. Jurnal Kesehatan Masyarakat Andalas. Diterbitkan oleh Program Studi Kesehatan Masyarakat Fakultas Kesehatan Masyarakat Universitas Andalas.

13. Rustyawati. (2005). Beberapa Faktor Risiko yang Berhubungan dengan Penyalahgunaan Narkoba pada Penderita yang Dirawat di Panti Rehabilitasi (Studi Kasus di Semarang dan Sekitarnya).

14. Soetjiningsih. (2004). Tumbuh Kembang remaja dan permasalahannya. Jakarta: Sagung Seto.

15. Sudarsono. (2005). Etika Islam Tentang Kenakalan Remaja. Jakarta: PT Rineka Cipta.

16. United Nations Office on Drugs And Crime (UNODC). (2015). World Drug Report 2015. New York: United Nations. 